\title{
MEMÓRIAS DA GRIPE ESPANHOLA... MEMÓRIAS DA COVID-19
}

Richarles Souza de Carvalho

Gladir da Silva Cabral

\section{DOI: http://dx.doi.org/10.18616/intcov15}

No artigo "O Pacto Autobiográfico, 25 anos depois", Philippe Lejeune (2014), estudioso da escrita de si, assume, com certo constrangimento, o quanto havia ignorado textos autobiográficos escritos por seu bisavô. Em tom confessional, ele admite o equívoco que havia cometido anos antes, quando pensava que era "[...] praticamente impossível que alguém que não tenha nenhuma experiência de composição literária, e cuja vida nunca tenha sido expressa por algum tipo de criação, escreva uma autobiografia tal como a definimos." (LEJEUNE, 2014, p. 87).

Por preconceito, ele achava que só gente famosa poderia produzir textos autobiográficos relevantes. Anos mais tarde, ele admite: "[...] menosprezei o talento de meu próprio bisavô, Xavier-Édouard Lejeune, comerciário e autor de uma autobiografia cujo verdadeiro modo de leitura levei 10 anos para descobrir." (LEJEUNE, 2014, p. 88).

Os escritos do senhor Pérsio de Carvalho, organizados postumamente em livro (não publicado), constituem fonte de estudo sobre a memória e o processo de escrita de si. Pérsio nasceu em 1909 e faleceu em 1986. Seu testemunho autobiográfico, escrito no final dos anos 1970, tem passagens interessantíssimas sobre a experiência de vida do sujeito, sua atitude perante desafios da existência, as escolhas bem como sobre o processo seletivo e de reconstrução da própria memória. Particularmente, há uma referência que o autor faz à gripe espanhola, que se espalhou pelo mundo entre 1918 e 1920 causando a morte de mais de 50 milhões pessoas.

Lembrando-se de sua infância, escreve:

A recordação amarga foi a da epidemia de gripe, a célebre "gripe espanhola", em 1918, uma das grandes epidemias 
mundiais. Dizia-se, na época, que tinha feito mais vítimas que a primeira grande guerra mundial, pois ainda criança, assisti nessa cidade de Cataguazes [sic], o seu cataclisma. Não havia uma só casa que não tivesse um doente. O número de vítimas mortais era enorme. Como criança, não tinha noção do que estava acontecendo. Recordo-me que em casa de minha tia, todos ou quase todos caímos doentes. O contágio era rápido e violento. Não havia médico para tratar e nem havia necessidade deles, sem tratamento específico. Das suas complicações cada um se tratava como podia e sabia. Quando muito, recomendações de cuidados gerais. Só sei que o tratamento que tivemos era: cama, aspirina e chá de melão São Caetano, um melãozinho que dá em forma de trepadeira. Pois, com este tratamento e a nossa resistência orgânica, não tivemos em nossa família nem um caso fatal. (CARVALHO, 1980, p. 8, grifo nosso).

A leitura dessa narrativa constrói semelhanças entre os fatos acontecidos durante a pandemia da gripe espanhola com os momentos vivenciados em 2020 na pandemia da covid-19. Pérsio era uma criança em 1918 e afirmou que não tinha muita noção do que estava acontecendo. As crianças em 2020 também não estão entendendo direito o que está acontecendo. E os adultos? Têm dimensão deste momento histórico?

Com sorte, daqui a alguns anos, biografias poderão ter algo de diferente em relação à narrativa do senhor Pérsio, por exemplo: as vítimas mortais em 2020 na pandemia da covid-19 não foram tanto quanto as vítimas da gripe espanhola. Oxalá também haja algo semelhante como: não houve em nossa família nenhum caso fatal.

\section{REFERÊNCIAS}

CARVALHO, Pérsio de. Memórias. 1980. Obra inédita.

LEJEUNE, Philippe. O pacto autobiográfico, 25 anos depois. In: LEJEUNE, Philippe. O pacto autobiográfico de Rousseau à internet. Tradução de Jovita Maria G. Noronha, Maria Inés Coimbra. 2. ed. Belo Horizonte: Editora da UFMG, 2014. p. 70-85. 